\section{Earth science: time for reassessment}

\author{
Gordon L. Herries Davies
}

Time's Arrow, Time's Cycle: Myth and Metaphor in the Discovery of Geological Time. By Stephen Jay Gould. Harvard University Press: 1987. Pp.222. \$17.50, £14.25.

Our author needs no introduction. Those who have enjoyed such earlier of Gould's books as The Panda's Thumb or Hen's Teeth and Horse's Toes will again find here the brand of entertainment that they relish. This new work arises from Gould's delivery of the first series of HarvardJerusalem lectures presented at Hebrew University in April 1985. It is a highly individualistic document (Gould admits it to be "a quest for personal understanding") and sometimes discursive (the book opens within the works of Sigmund Freud and closes outside the south front of the Cathedral of our Lady of Chartres), but it is always highly readable. To style it "stunning", as does the publisher on the dustjacket blurb, is to indulge in hyperbole. But vastly entertaining and stimulating it most certainly is.

Gould's subject here is geological time; he is concerned with certain aspects of the discovery of what John McPhee has appropriately termed "deep time". The story of that discovery, from seventeenthcentury exegesis to twentiethcentury radiometric dating, is a tale oft told, and there is within Gould far too strong a pioneering instinct to allow him to rest content with the following of so well-trodden a trail. His is a more subtle approach.

$\mathrm{He}$ has given his book two overt themes. The main theme - whence the book derives its title - involves Gould's contention that as we in the Western world look back over the history of our globe we are torn by a conceptual dichotomy. On the one hand we believe in the arrow which moves steadily through time. Behind it there stretches a past now irredeemably lost to us; before it there lies a future which the arrow's continued flight steadily converts first into an instantaneous present and then secondly into the latest increment of an accumulating past. This concept of the arrow of time can hardly be unrelated to the presence within the Christian faith of a linear, directional view of history which traces events from a Creation, through a Fall, an Advent and a Crucifixion, to a future Parousia and a coming Millennium. But Gould is con- vinced that mankind is less than happy with the arrow of time. It allows us to interpret history only as a series of unique events whereas "we also crave some underlying generality, some principles of order transcending the distinction of moments" (p. 196). The result of this craving is the interpretation of history not as a series of unique linear events but, rather, in terms of a series of continuously repeated cycles. This cyclic interpretation, one which seems to have found favour among most human societies, is the second element within Gould's dichotomy.

In the book Gould explores these two metaphors - the arrow and the cycle - in the context of geology's discovery of deep time, and he has clearly found satisfaction through his recognition of the dichotomy between them. "For me", he writes (p.191), "this contrast became a key for unlocking both the structure and meaning of great historical documents that I had read several times before, but had never understood or grasped as unified statements". This, the first of Gould's two themes, is clearly of interest to all manner of intellectual historians.

The second theme - the sub-plot - is directed expressly towards practising Earth scientists. Here Gould emphasizes for the benefit of all such readers that much of what passes for the history of the Earth sciences really bears scant relationship to the true passage of past events. Over the past 25 years a great deal of incisive scholarship has been directed towards the history of the Earth sciences, but as yet these studies have made little impact upon the historical understanding of the Earth sciences community at large. It is to be hoped that Gould's message will now get through to those quarters where it is most urgently needed. Those preliminary lectures - those textbook introductions - based upon nothing more sub-

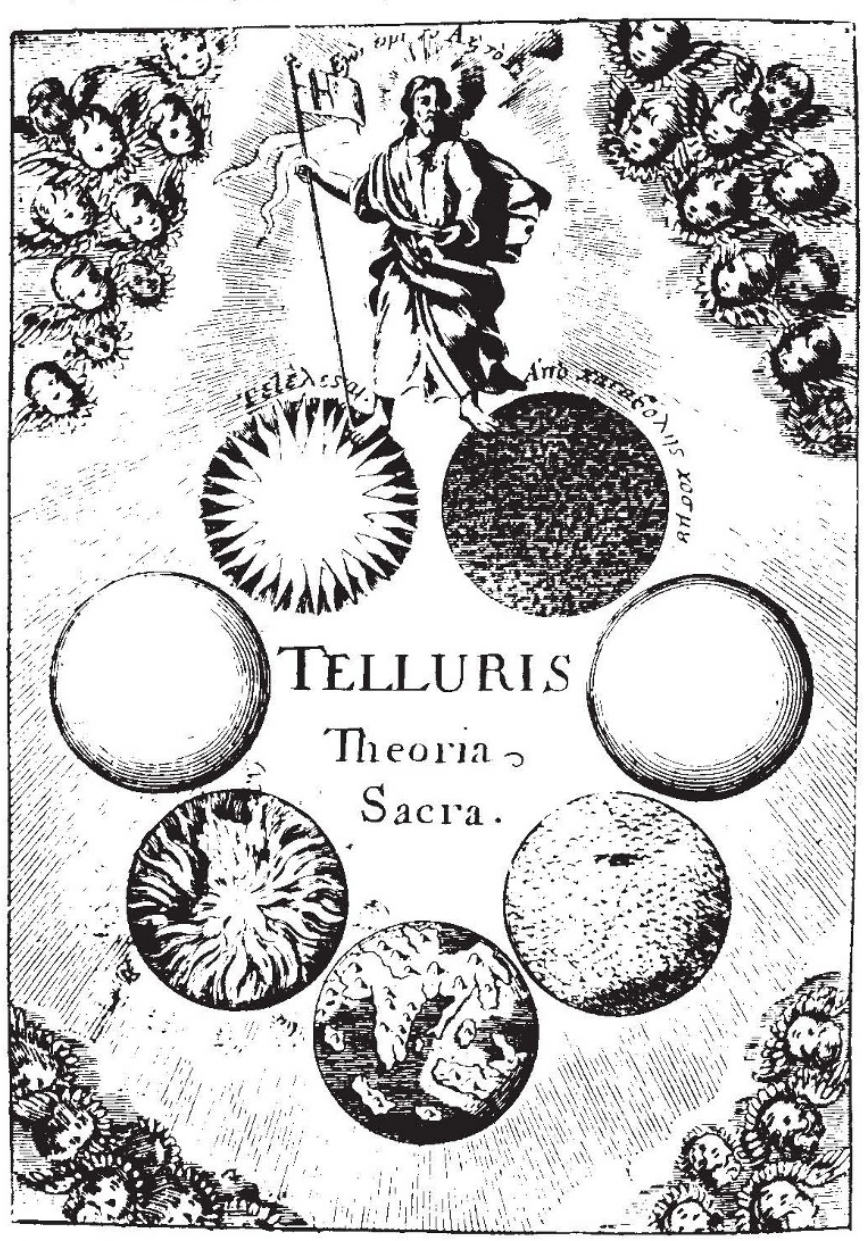
Telluris Theoria Sacra of 1681. The spheres represent the successive phases in the history of the Earth following a clockwise sequence from the top right as follows: (1) The chaotic liquid; (2) the Earth in its pristine state; (3) the Earth during the Flood; (4) the modern Earth; (5) the Earth during the conflagration which will precede the Parousia; (6) the Earth during the Millennium; and (7) the Earth in its ultimate state as a star. (Reproduced from Time's Arrow, Time's Cycle.)
From beginning to end - the frontispiece from Thomas Burnet's stantial than Sir Archibald Geikie's The Founders of Geo$\log y$ of 1905 just will not suffice today. At best, such derivations from Geikie perpetuate simplistic half-truths; at the worst they perpetuate those popular myths which Gould brands as "textbook cardboard".

Gould here makes no attempt to demonstrate the validity of his theses through a comprehensive analysis of European literature at large. He prefers to adopt the case-studies approach, and offers a trio of refreshingly original essays devoted to the major publication of just three of the British scholars who loom large in virtually all our histories of the Earth sciences. The chosen three (one standard villain and two standard heroes, as Gould puts it) are Thomas Burnet as mirrored in his Telluris Theoria Sacra of 1681 and 1689, James Hutton as mirrored in his Theory of the Earth of 1795 and Sir Charles Lyell as mirrored in his Principles of Geology of 1830 to 1833.

Burnet and his theory have been harshly treated by a posterity which expects a history of the Earth to be based upon the study of subduction zones and unconformities rather than upon the Pentateuch and soaring flights of the human imagination. But Gould adopts a timely revisionist stance and he reminds us first that by the standards of his day - and what other standards may we justly employ? - Burnet was 


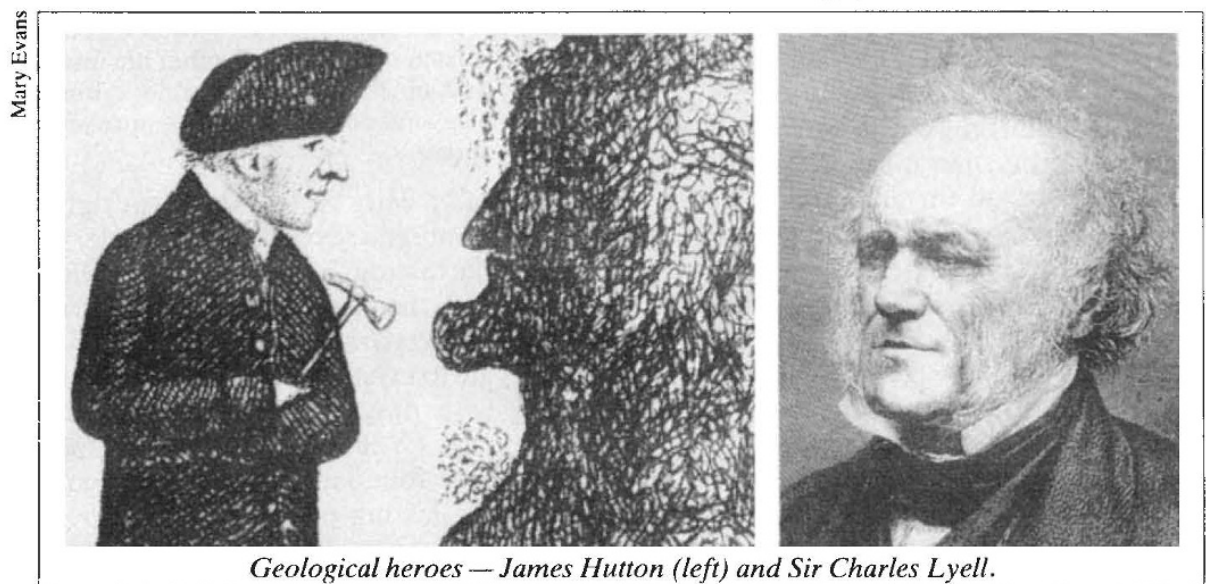

a fine scholar, and secondly that throughout his work Burnet was at pains to demonstrate the efficacy of natural processes to account for all the postulated events of Earth history. More especially, he refused to invoke miraculous intervention. In this respect he is entitled to stand higher in our estimation than is Sir Isaac Newton because, in his correspondence with Burnet, Newton expressed the view that God might occasionally have interfered to change the Earth's speed of rotation.

It is upon the frontispiece to Burnet's Theory that Gould focuses particular attention and he sees it "as the finest expression ever published of the tension between two complementary views of time" (p.41). In many histories of the Earth sciences Burnet's whimsey is contrasted with the more securely field-based theory of the Earth published by Nicolaus Steno in 1669 , but in a tailpiece to his essay Gould suggests that in reality both men were influenced by that same dichotomy between time's arrow and time's cycle.

In turning to James Hutton, Gould confronts one of the most revered figures in the history of the Earth sciences; in 1947 there was placed upon Hutton's Edinburgh grave a tablet proclaiming him to have been "The founder of modern geology". In this essay, Gould looses a flight of well-aimed bolts. First, he joins other recent authors in attacking the Geikiederived myth that Hutton's theory of the Earth was the masterpiece of an empiricist deeply experienced in field phenomena. In reality, at the time of its formulation Hutton's theory was no more securely grounded upon observational evidence than was Burnet's, although it does need to be emphasized that the recently rediscovered illustrations that were to have accompanied the unpublished third volume of Hutton's Theory of 1795 reveal that late in his life Hutton did indeed become a true field geologist. Secondly, Gould argues that in Hutton's theory we see reflected a mind which has decisively rejected the arrow of time in favour of the cyclic view. I find this thesis persuasive. We must hope that the interpretation will now be further explored in the context of the eighteenth-century deistical movement of which Hutton was a part. Thirdly, Gould observes that those who have criticized Hutton for his failure to enlist palaeontology and stratigraphy in the cause of his theory have misunderstood their man. Hutton, Gould claims, deliberately shunned fossils and the stratigraphic column because he had no concern for any kind of directionality in Earth history. He was interested solely in the Earth as a selfrepairing, steady-state, perpetual-motion machine.

Gould's third essay - the longest and most closely reasoned - is devoted to Charles Lyell's brilliant Principles, and here he returns to a number of the points already made in connection with Hutton's theory. In Gould's own words, the object is to demonstrate that "Lyell was no impartial empiricist, but a partisan thinker committed to defending time's cycle against a literal record that spoke strongly against a directionless world..." (p.103). It is a thought-provoking piece of writing which will command the attention of all Lyell scholars.

Underlying the entire book, however, lurks yet another and still deeper theme which should commend the work to a readership far wider than historians of ideas and of science. Gould both explicitly and implicitly demonstrates that science is a creation of human minds which are ever feeling the influence of pressures far removed from those natural phenomena that are laid out before the scientist's gaze. Sir Peter Medawar has repeatedly reminded us that "The purely logical element in scientific discovery is a comparatively small one". Gould amply demonstrates precisely this point. Geology is not some mysterious miasma which gradually seeps from the Earth's surface to be collected and analysed by the Earth scientist. Rather is it a secretion which oozes generation by generation out of the human cerebrum.

Gordon L. Herries Davies is Associate Professor of Geography at Trinity College, University of Dublin, Dublin 2, Ireland, and is General Editor of the Dictionary of Irish Biography.

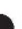 \\ SPRING BOOKS}

FROM LONGMAN

SCIENTIFIC \& TECHNICAL

\section{THE DINOSAUR HERESIES}

\section{By Robert Bakker}

Overwhelming evidence that, far from being a flawed dynasty of sluggish monsters plodding through the swampy Mesozoic terrain, the dinosaurs were a warm-blooded and highly successful species.

April ISBN 0582004209 Cased $£ 14.95$

\section{SECRETS OF SLEEP}

By Alexander Borbély

Why do we sleep? Why do we dream? Can we reduce our need for sleep? What can be done about insomnia? All these questions and more are answered in this enthralling exploration into the world of sleep.

April ISBN $058200537 \times$ Cased $£ 10.95$

\section{ORGANIC CHEMISTRY}

FOR STUDENTS OF BIOLOGY AND MEDICINE

\section{By Giles Taylor}

A unique and comprehensive text, now revised and updated for this third edition. which provides the student of the life sciences with the basis for getting to grips with the chemica! aspects of life processes.

May ISBN 0582447089 Paper $£ 10.95$

\section{THE MICROBIOLOGY OF TERRESTRIAL ECOSYSTEMS}

\section{By Bryant Richards}

Micro-organisms are often neglected in ecological textbooks. Here, Bryant

Richards attempts to redress the balance by emphasising the role of soil organisms, especially fungi and bacteria in maintaining productive ecosystems.

May ISBN 0582450225 Paper $£ 17.95$

\section{MODERN SELECTIVE FUNGICIDES}

\section{Edited by Horst Lyr}

A team of international specialists describe the properties and antifungal spectra of selective - and mainly systemic - fungicides, dealing with their practical applications in agriculture. horticulture and timber preservation. A definitive source for agronomists. foresters and biochemists

May ISBN 0582004616 Cased $£ 30.00$ (est)

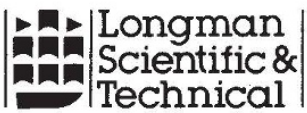

Available through your bookseller. For further details on these and related titles. write to Clive Weatherley, Longman House Burnt Mill, Harlow, Essex, CM20 2JE, UK. 